\title{
Urbanization and Arable Land Use in Northern Ghana: A Case Study of the Sagnarigu Municipality in the Greater Tamale Area
}

\author{
Mohammed Muniru Abubakari ${ }^{1}$, Kwabena Asomanin Anaman ${ }^{2}, \&$ Ama Asantewah Ahene-Codjoe ${ }^{3}$ \\ ${ }^{1}$ Teacher, Anbariya Islamic Senior High School, Ghana Education Service, Tamale, Ghana \\ ${ }^{2}$ Professor, Department of Agricultural Economics and Agribusiness, University of Ghana, Legon, Accra, Ghana \\ ${ }^{3}$ Lecturer, Department of Agricultural Economics and Agribusiness, University of Ghana, Legon, Accra, Ghana \\ Correspondence: Kwabena Asomanin Anaman, Department of Agricultural Economics and Agribusiness, University of \\ Ghana, Legon, Accra, Ghana.
}

Received: December 27, 2021

Accepted: January 31, $2022 \quad$ Available online: January 31, 2022

doi:10.11114/aef.v9i1.5469

URL: https://doi.org/10.11114/aef.v9i1.5469

\begin{abstract}
We analyzed the effects of urbanization on the use of arable land in the Sagnarigu municipality in the Greater Tamale Area of Ghana. The study involved a random survey of 300 farming households to establish their land-use patterns and valuation, and an analysis of satellite and remote sensing data for the years, 2000, 2010 and 2020 for land-use related land cover changes in the area. Out of 300 responding household heads, $88.3 \%$ were land users with usufructuary rights; the remaining $11.7 \%$ were tenants. The hedonic pricing method was used to analyse arable land values. The value of arable land was negatively influenced by the distance to the nearest main road, district capital town, and Tamale Central Business District, and positively influenced by its closeness to State institutions. Urbanization, proxied by the population of the community where the land was located, positively influenced the value of the land. Based on the analysis of geographic information system data, we established that the built-up area in the district increased from 13.0 $\mathrm{km}^{2}$ in 2000 to $97.5 \mathrm{~km}^{2}$ in 2020, an increase of $650 \%$. Built-up area accounted for $48.7 \%$ of the total land available in the district in 2020 .
\end{abstract}

Keywords: hedonic pricing method, Ghana, land use, land valuation, urbanization

\section{Introduction}

\subsection{Background}

Feeding the increasing human population, in a world with increasingly-limited arable land and water resources, has become a major challenge for humanity. There is some concern that the resources of the planet could soon restrict the ability of human beings to keep up with the increasing food demand required by people (Godfray et al., 2010). Urbanization and changes in human diets have increased pressures on agro-ecosystems and worsened food insecurity (Johnston et al., 2011). The growing demand for land, characterized by the purchase and long-term leases of vast lands from developing countries by wealthier nations, has increased pressure on cultivatable land in developing countries.

Urbanization is a major cause of loss of agricultural lands in developing countries (Daniel, 2011). Urbanization is the change or shift from a rural setting to an urban setting, and the increase in the proportion of people living in the urban areas and how they adapt to this change (Naab et al., 2013). A United Nations report produced in 2019 indicates that urbanization is as a complex socio-economic process that transforms the built environment, converting rural into an urban settlement, and also shifting population from rural to urban areas (United Nations Population Division, 2019).

People move from rural areas to urban centres for reasons such as seeking greener pastures in terms of economic empowerment, and to have a taste of urban life, just to mention a few reasons. These rural-urban movements of people force governments to increase their infrastructural development in the urban centers. The rise of human population also pushes and displaces farmers in the urban and peri-urban areas out from good agricultural lands because of high demand for housing and certain social amenities in the urban areas. Agricultural land losses often occur in the urban and peri-urban areas where there are high-quality farmlands. This is a major concern because land does not increase as population grows; urbanization and land conversion pose a threat to urban agriculture (Kuusaana and Eledi, 2015). 
Land conversion is a method where land is modified from one state to another often involving a change in human use. The conversion of agricultural lands has resulted in much debate as to whether agricultural lands should be converted or maintained. This debate involves different perspectives of rural and urban supporters. Rural supporters believe that to meet the food demand of the growing population, the size of agricultural lands should be maintained. Urban supporters believe that agricultural land conversion is a fair result of modernization and that technological advancements can solve the issue of declining agricultural production (Azadi et al., 2010; Malik and Ali, 2015; Nguyen et al., 2019).

The issues of land conversion and urbanization are of particular concern to African countries such as Ghana. As at 2018, Africa had about 548 million people living in its urban centres. African urban population is likely to triple between 2018 and 2050. With about 1.5 billion increase in urban dwellers projected in 2050, Africa will account for about 22 percent of the world urban population at that time (United Nations Population Division, 2019). With this expected increase in urban population and the continuous increase in land conversion as a result of urbanization, can the growing urban dwellers in Africa be fed if valuable agricultural lands in peri-urban centres continue to be reduced?

\subsection{The Problem Statement}

Tamale is arguably the fastest growing city in the world by population. Given that Tamale is predominantly inhabited by Muslims, hence it is also the fastest growing Muslim-majority city in the world. The population of Tamale City (Tamale Metropolitan, Tamale South and Tamale Central districts) was 749,488 in July 2021 (Ghana Statistical Service, 2021, page 60) compared to the September 2010 population of 233,252 (Ghana Statistical Service, 2014a, page 20). The city's population increased by 516,236 or $221.3 \%$ in just under 11 years.

The study area, Sagnarigu Municipality is a peri-urban district of Greater Tamale Area, where many people working in Tamale Metropolis reside. Rapid urbanization in Sagnarigu municipality has resulted in the conversion of agricultural lands into built-up facilities. This has weakened the interest among the displaced farmers who want to continue cultivation. Many poor urban farmers being displaced still engage in some form of agriculture based on backyard gardening and subsistence agriculture (Ghana Statistical Service, 2014; Damba et al., 2019).

This continuous engagement with agriculture in the midst of rapid loss of arable lands by urban farmers is due to their lack of capital to invest or the inadequacy of resources to move further into the hinterlands to engage in agriculture. If urbanization and land conversion continue without adequate provisions and enforcement of laws to protect agricultural lands in the district, an increase in urban unemployment and food insecurity could occur. This situation will affect poor urban farmers who lack the economic means to go into hinterlands to continue production.

Sagnarigu Municipality (district) was carved out of the Tamale Metropolitan Area in 2012 (Ghana Statistical Service, 2014). The district is well known for its urban and peri-urban agriculture that feeds the growing population of Tamale and the rest of the country. The population of the Sagnarigu district was 148,099 in 2010 (Ghana Statistical Service, 2014 b). This population increased to 341,711 in 2021, with the urban share being $81.6 \%$ up from $63.2 \%$ in 2010 (Ghana Statistical Service, 2021). The increase in population of 193,612 (131\%) over a period of just under 11 years could be attributed to increases in migration and also an increase in the fertility rate.

The objectives of this study were to ascertain the nature of the land tenancy and ownership status of farmers, to analyse the factors influencing arable land values, and establish the effect of urbanization on land-use changes in the Sagnarigu municipality. The remainder of this paper is structured as follows: the next section deals with the review of the literature and is followed by the theoretical framework and the methodology. The results and conclusions of the study follow.

From a political-economy perspective, this study, situated in the research area of societal impacts of economic growth, and focusing on the Greater Tamale Area (GTA), is of international interest. The GTA is a predominantly Muslim area close to the border countries of Burkina Faso and La Cote d'Ivoire, and the Muslim-majority countries of Chad, Libya, Mali, Niger, Nigeria and Sudan, where Islamic insurgency movements have been prominent over the last decade, and have influenced the staging of military coups over the last nine months in Burkina Faso, Chad and Mali. These movements, which include the Boko Haram and Islamic State, have waged attacks on government forces across Africa. Large numbers of displaced farmers arising from urbanization, who remain unemployed, are potential recruits for insurgency movements.

\section{Literature Review}

\subsection{Overview of Political Economy of Governance and Economic Growth in Ghana}

\subsubsection{Political Economy of Governance in Ghana}

Ghana is situated in West Africa and had population of 30.8 million (July 2021) growing at $2.1 \%$ annually (Ghana Statistical Service, 2021). The country, was formerly called the Gold Coast due to the very large amounts of gold and other minerals discovered in the country by European explorers and traders starting from the 15th Century. Ghana gained its independence from Great Britain on 6 March 1957 after 113 years of colonial rule. The independence struggle 
was led by Dr. Kwame Nkrumah and the Convention People's Party. Dr. Nkrumah was elected the First Republican President on 1 July 1960 when Ghana became a Republic. The country went through a 27-year period of political instability from 1966 to 1992, marked by five military coups, after the first military coup on 24 February 1966. Since the start of the Fourth Republic in January 1993, Ghana has had political stability, albeit with continuing challenges related to intense two-main-political-party polarization of society. These challenges are characterized by permanent electioneering campaigns and intermittent political violence orchestrated by the two main political parties in the country, the ruling New Patriotic Party and the main opposition party, the National Democratic Congress.

Ghana is currently administered through 16 regions, 261 districts, and about 190 traditional (chieftaincy) councils. These traditional councils belong to 89 individual tribes which come from nine broad ethnic groups in the country. Tamale is the biggest town in the five regions of Northern Ghana. Northern Ghana is the poorest part of the country partly due to its unimodal patterns of rainfall which limit the productivity of rain-fed agricultural production (Baimbill-Johnson et al., 2021). The environmental capital of Northern Ghana has also been affected by climate change (Salifu and Anaman, 2019).

\subsubsection{Political Economy of Economic Growth in Ghana}

The economy of Ghana experienced positive annual growth, based on changes in the gross domestic product (GDP), for a 38 -year period, from 1984 to 2021, with the annual growth averaging 5.2\%; ranging from a low of $0.4 \%$ in 2020 to a high of $14.0 \%$ in 2011, since the introduction of major structural adjustment programmes supported by the International Monetary Fund and World Bank in April 1983. These programmes were undertaken after 18-year period of low and erratic growth, from 1966 to 1983 , linked to political instability related to military coups, and El Nino weather-related events, which produced very severe droughts throughout the country in 1977, 1978, 1982 and 1983 (Anaman et al., 2017).

The continuous economic growth, since 1984, has been cited as an African success model in some quarters (for example, refer to McMillan et al., 2017). However, this growth has resulted in considerable costs to the natural environment, and also to human society, through the rapid build-up of very large government debts, intertwined with very high debt service costs, increased marginalization of small tribes (Anaman and Bukari, 2019, 2021), and very high numbers of fatalities arising from mining, work and road accidents. Ghana is ranked $23^{\text {rd }}$ in the world in road fatalities out of 183 countries (World Health Organization, 2018). In terms of the country's debts, public debts-to-GDP ratio reached $78.4 \%$ in November 2021 (Bank of Ghana, 2022); foreign debts increased from 2.1 billion United States (US) dollars in December 2006 (Bank of Ghana, 2022) to 27 billion US dollars in December 2021 (Bloomberg News, 2022).

The economic growth has been characterized by large scale environmental destruction, including severe pollution and/or destruction of about $60 \%$ of the country's rivers through mining activities (Kusimi et al., 2013; British Broadcasting Corporation, 2021), poor sanitation quality (Yale University, 2021), massive deforestation and considerable encroachment of forest reserves (Amoah and Korle, 2020; Acheampong et al., 2021), and rapid growth in air pollutants, such as sulphur dioxide, particulate matter, and greenhouse gas (GHG) emissions (Ghana Environmental Protection Agency, 2019). The growth of GHG emissions is now dominated by non-hydro electricity generation and the transport industry; the GHG emissions from the transport industry are linked to an exponential growth in used road vehicles.

Ghana also has one of the fastest and steadily-growing income inequality in Africa. The Gini coefficient income inequality index for Ghana was 35.3 in 1987; it increased to 38.4 in 1992. This index increased to 40.1 in 2000, and further increased to 41.9 in 2006, 42.3 in 2013, and then to 43.5 in 2017, an 8.2 point increase of the index within 30 years (World Bank, 2021). While the average national average poverty rate declined slightly from 2013 to 2017 (Ghana Statistical Service, 2018), the poverty rates, including severe food insecurity index, of many of the 80 relatively small tribes in the country, increased significantly over this period (Anaman and Bukari, 2021).

National income, commonly measured by GDP, is earned by workers (labour), owners of human-made capital inputs, such as machinery, and owners of environmental capital inputs, such as arable land. A characteristic of Ghanaian economic growth had been the steadily-increasing share of national income going to owners of human-made capital assets, arising from large-scale conversion of environmental capital inputs into human-made capital assets. There had been declining share of national income accruing to owners of environmental capital inputs, and little change in the share of national income going to workers which had remained around 45\%, from 1993 to 2012 (Anaman and Agyei-Sasu, 2014).

Overall, the quality of Ghanaian economic growth performance over the last three decades has been exaggerated. The exaggeration is due to the double counting of environmentally-destructive activities, non-subtraction of environmental cleanup and repair costs from incomes in GDP estimation, and the neglect of the negative societal impacts of economic growth. For example, the large-scale abandonment of uncompleted public investment projects, when a new political party takes power in Ghana, commonly observed during the Fourth Republican era, increases government debts with little positive societal impact of these projects, despite them being captured in GDP growth figures of the previous years. 


\subsection{Concept of Land Ownership, Land Acquisition and Land Grabbing}

Land ownership implies the rights to use a piece of land in ways specified by the laws of the State and Community obligations. Ownership of land gives the rights of transferability of the asset to another individual. In Ghana, there are three main systems of land ownership. These are public land ownership, customary land ownership, and "vested land" ownership. Public lands in Ghana fall into two categories, land which is compulsory acquired for public interest under the State Land A of 1962 (Act 125), and lands which have been vested in the President under the Administrative Land Act 1962 (Act 123). Vested lands have dual ownership based on combination of customary ownership and public ownership. Public lands are those lands that are owned collectively by the citizens of Ghana (Yeboah and Shaw, 2013).

Land acquisition is a term that refers to a process whereby individuals or groups obtain pieces or parcels of land for their use including the development of the land. Compulsory land acquisition is often used by the State or government authorities for the purpose of securing land for development purposes, which may include the protection of specific environmental resources, including non-human animal species facing extinction. Land acquisition then implies a change of ownership or the reinforcement of ownership of particular pieces of land. Land grabbing refers to a process through which local or foreign agencies acquire land through the purchase of land. It is also defined as the purchase or lease of land on unsettled terms between the buyer and those already living on the land (Murphy, 2013), or the acquisition of land that is not based on the informed consent of affected land users (Blomley et al., 2013).

\subsection{Land Ownership and Agricultural Production}

Land ownership and tenure security are important contributors to food security, enhancement of livelihood opportunities, and poverty reduction (Food and Agriculture Organization, 2011). Urbanization and population increase result in a rise in the demand for land and consequently increased land prices. With increasing land prices, customary land trustees tend to allocate land for the financial benefits accruing to themselves, often paying less attention to community benefits (Yeboah and Shaw, 2013). However, due to escalating land prices, many urban poor, whose source of livelihood is from subsistence agriculture, find it difficult to access land. When they are able to acquire some parcels of land for farming purposes, they are forced into continuous cropping on the same pieces of land from year to year due to the lack of capital to acquire additional pieces of land under cultivation. Urbanization causes an increase in land use intensification; productivity declines without the use of modern inputs such as fertilizers (Iheke and Nto, 2010).

Farmers in urban and peri-urban areas who lack farming space (land) to cultivate on take advantage of unused plots of land for cultivation. Urban and peri-urban farmers, who lack cultivable space or secured land, cultivate their crops on vacant spaces, alleyways, and wetlands. Many such farmers do not know the owners of the private land that they use until they begin developing them (Kuusaana and Eledi, 2015). Place (2009) argues that the acquisition of secure land rights does not necessarily mean an increase in agricultural production by farmers. Rather, it is the investment in agricultural inputs that boosts production. Some customary landowners take advantage of the high demand for land in areas close to highly populated localities to enrich themselves by selling their lands to developers (Soussou and Mbaye, 2018).

\subsection{Concept of Urbanization}

Urbanization involves an increase in residential population and extension of non-farm activities. Many countries use population thresholds to classify towns as urban (Moreno, 2017). In Ghana, urban communities are those classified by the Ghana Statistical Service as having a population of 5,000 or more (Ghana Statistical Service, 2013). In Denmark and Iceland, urban localities refer to communities having at least 200 inhabitants (Moreno, 2017). In Nigeria, 20,000 inhabitants constitute an urban locality (Naab et al., 2013). Another definition of urbanization is that it is the product of social, economic, and demographic processes that concentrate populations in large towns and cities, result in changes in land use, transform economic structures and alter social lifestyles and relations (Cobbinah et al., 2015).

Both positive and negative benefits of urbanization to society are identified in the literature. The negative effects of urbanization are much more noticeable with the loss of pristine lands for agricultural production both in the rural areas and urban centers. Urbanization affects all sectors of the economy and all spheres of life in both rural and urban settings. Urbanization generally results in sprawling patterns of cities, expansion of slums, increasing urban poverty, and widening income inequality among the population of many countries (United Nations Habitat, 2017).

The world population has been urbanizing fast in more recent times; between 1950 and 2018, the urban population of the world grew more than four-fold. In 1950, only 30 percent of the world's population lived in urban areas, made up of 0.8 billion people. The global urban population reached one billion in 1959; it took 26 years to reach two billion in 1985; it reached three billion in 2002 taking another 17 years to reach that level. By 2015, the world's urban population had reached four billion (United Nations Population Division, 2019). 


\subsection{Urbanization and Arable Land Use}

Urbanization causes competition between lands used for agricultural production and lands used for urban industrial development and housing. There is a perception that arable land conversion is inevitable during periods of rapid population growth. As population increases, areas for urban settlement are preferred to areas for agricultural production, especially when food shortages do not exist (Tenaw et al., 2009). As a city grows, prime agricultural lands are turned into non-agricultural uses. Urbanization and population pressure have led to increases in land values; landowners prefer allocating their lands for the highest prices rather than their highest value uses (Naab et al., 2013; Lasisi et al., 2017).

The rate of agricultural land conversion in an Indonesian case study in East Java was estimated to be 187,720 hectares per year (Rondhi et al., 2018). In Concepcion (a Chilean city) it was estimated that 1,417 hectares of agricultural and forest lands were converted into residential areas over a period of 25 years (Pauchard et al., 2006). Appiah et al. (2014) indicated that some Ghanaian landowners converted their land from agricultural uses to non-agricultural uses due to relatively high prices offered for land for non-agricultural uses. Similarly, Anaman (2001) showed that the reduction of arable land for rice production in Brunei Darussalam was due to the demand by businessmen for development of real estates and other construction-related assets.

As Africa is increasingly becoming urban, it is important for African governments to strengthen their agricultural sectors through preserving agricultural lands if the growing numbers of people are to be sufficiently fed. Bayo (2006) estimated that an African city of four million inhabitants would require about 3,000 tonnes of food a day. Given this high level of food demand by urban inhabitants, it is crucial to for governments to strengthen their policy initiatives that advance the development of urban agriculture. Urban agriculture is not only a livelihood source for the urban poor but also, it serves as an immediate access/source of food for vulnerable urban dwellers.

\subsection{Land Tenure Status of Farmers}

Land tenure deals with the terms and conditions under which land is held, used, and exchanged (Adams and Adams, 2001). Land tenure security is the perceived right that an individual has over a land on a continuous basis, free from imposition or interference from outside sources, as well as the ability to reap the benefits of labour and capital invested in the land either in use or upon transfer to another holder. Land tenure is the right of people to own, use, and control land and its resources (Simbizi et al., 2013; Idoma and Ismail, 2014). Land tenure can be classified into three types as follows: legal ownership based on freehold rights, customary ownership, and squatting (Soussou and Mbaye, 2018).

Legal ownership is the highest form of security where farmers acquire legal certificates over the land. Customary land ownership offers individuals, within the clan, use rights but not full ownership rights. Squatters have low level of security because the land belongs to someone else. Another three-group classification based on tenure exists (Idoma and Ismail, 2014). This is made up of the freehold system of tenure, communal, and rental-based tenure. Freeholders are more land secure than communal landholders. Communal landholders have more security than renters.

The three different forms of land tenure security (rights) in Africa are due to the large number of different groups, different rates of population growth, and the level of influence that governments have on tenure arrangements (Place, 2009). Some research workers suggest that the ability to fallow land needs to be incorporated into the definition of land security (for example, refer to Alemu, 1999). The ability to rest the land through land fallowing reflects more secure land use rights. If a farmer fears that he/she will lose a piece of land that is being fallowed, it generates a large degree of uncertainty in his/her production plans (Ghebru and Lambrecht, 2017).

\subsection{Concluding Comments}

The review of the literature indicates that economic growth occurs partly through the conversion of environmental capital inputs, such as arable land, to human-produced assets and facilities. Further, the review suggests that locality-specific factors influence the effects of the conversion of environmental capital inputs into human-produced assets. These effects include changes in land uses and land values, and suggest the need for local studies, such as the current one, to unravel important factors affecting arable land losses and impacts of these losses on affected communities.

\section{Theoretical and Conceptual Frameworks}

\subsection{Underlying Political Economy Theories}

A mix of two theories is used as the combined theoretical framework of this study in line with political economy analysis of development which involves the integration of various schools of thought in research work to improve understanding of societal phenomena, often not possible through the rigid use of one school of thought. The neo-classical economics approach to household organization assumes that a household is a single decision-making unit with a common agreed utility function. The alternative collective household theory is used in this study. There are two classes of collective household theory - cooperative and non-cooperative (Chiappori et al., 1993). 
The focus of this study is on the cooperative household theory where an individual has a choice to be single or to form a household. Individual household members have preferences; each member decides which crops/livestock to produce; how he/she acquires his/her land and nature of the security afforded to him/her in the use of the land. The collective approach suggests that multi-person households consist of members who may have different preferences. Household formation has added benefits, such as love and companionship services, enshrined in marriage. The household generates a surplus which is distributed across its members. Models derived from this approach assume that within-household bargaining results in Pareto-efficient outcomes. A logical deduction from this theory is the existence of relatively stable multi-person households, engaged in various enterprises, which are in consonance with the laws of the State and Community rules.

The second component of the theoretical framework is the hedonic pricing model derived from neo-classical economics principles. The hedonic pricing model (HPM) suggests that the value of unpriced or non-market good is directly related to the attributes embedded in the good including internal and externally-linked characteristics. The theory underlying HPM is the Lancaster demand theory developed by Australian economist, Kelvin Lancaster in 1971. The theory asserts that the consumer is interested in the attributes and the characteristics of the good that he/she demands rather than the good per se. The Lancaster demand theory, when applied to analysis of land values, has its antecedent in the hypothesis formulated by the German political economist, Johann Heinrich von Thunen in 1826. The von Thunen hypothesis deals with the allocation of land for production of various crops at different locations from the central city (Norton, 1979).

The Lancaster demand theory is the third variant of neoclassical economic theory of demand. The first is the traditional Marshallian demand function developed by the British economist, Alfred Marshall in 1890 which involved the maximization of the utility function of a consumer subject to his/her budget constraint. The second demand function is the Hicksian demand function which originated from the British economist, John Hicks in 1939; it involves the consumer minimizing his/her total expenditures on all goods and services while maintaining a fixed level of utility.

\subsection{Conceptual Framework}

The conceptual framework of the study is based on a three-layer concept of causes, effects and consequences. Urbanization is caused by factors such as rural-urban migration, natural increase in peri-urban and urban population, and increased economic activities. These factors influence changes in land use and land values, changes in customary land allocations and competing land uses between agricultural and non-agricultural uses. The societal consequences from land use changes are expressed through outcomes such as increased food insecurity and unemployment.

\section{Methodology}

\subsection{Methods of Survey Data Collection}

Primary data were sourced from selected households using structured questionnaire, containing closed and open-ended questions; data were gathered from the required individuals, targeted persons, and groups for this study. Data were also sourced through structured, semi-structured, and key informant interviews, field surveys, and observations. Key informant interviews and group discussions were conducted to get in-depth information. A multi-stage sampling technique was adopted to stratify the study area into communities based on guidelines provided in several published works (Anaman, 1988; Anaman, 2014; de Vaus, 2014). Ten peri-urban communities in the district were purposively selected.

The random sampling method was used to select respondents in each of the ten selected peri-urban communities. Each household was identified through a residential house. The random sampling of residential houses was carried out using a table of random numbers generated from a scientific calculator to choose houses. In all three hundred (300) household heads were interviewed. The optimal sample size of 300 was based on the use of statistical formulae reported by de Vaus (2014), based on the knowledge that $36.5 \%$ of all households were engaged in agriculture. Further, another 122 out of the 300 respondents were randomly selected for the valuation of their land plots. This exercise involved the selection of 122 plots of land. These 122 similarly-sized plots were assessed for their values based on interactions of the household heads with officers from the Land Valuation Board, who were recruited by the researchers, to properly value the land. The choice of 122 respondents instead of all 300 household heads was due to the high costs of hiring specialist land valuers.

\subsection{Methodological Application of the Hedonic Pricing Theory}

Hedonic pricing theory indicates that the value of an asset is a function of its attributes (Brown and Rosen, 1982; Bartik, 1987; Anaman et al., 2000; Engstrom and Gren, 2017). Guided by this theory, the value of land in the Sagnarigu district is modelled using the formula in Equation 1.

$$
\mathbf{Y}=\mathbf{B}_{0}+\mathbf{B}_{1} \mathbf{X}_{1}+\mathbf{B}_{2} \mathbf{X}_{2}+\mathbf{B}_{3} \mathbf{X}_{3}+\mathbf{B}_{4} \mathbf{X}_{4}+\mathbf{B}_{5} \mathbf{X}_{5}+\mathrm{U}
$$

Equation 1

Where $\mathrm{Y}=$ Price of the land/value of land in Ghana cedis. 
$\mathrm{X}_{1}=$ Distance of the land to the Tamale Central Business District (CBD).

$\mathrm{X}_{2}=$ Distance of the land to the nearest main road.

$\mathrm{X}_{3}=$ Distance of the land to the district capital town.

$\mathrm{X}_{4}=$ Number of people in the community; this variable is used as a proxy for urbanization.

$\mathrm{X}_{5}=$ Closeness of the land to the nearest State institutions. This is a dummy variable with a value of 1 if land is located

1.2 kilometres or less from State institutions, and zero if the distance is greater than 1.2 kilometres.

$\mathrm{B}_{0}=$ Intercept; $\mathrm{B}_{1}$ to $\mathrm{B}_{5}$ are coefficients of the explanatory (independent) variables.

$\mathrm{U}=$ Error term assumed initially to be normally distributed with zero mean.

The natural logarithmic function of the model was used for the analysis based on recasting Equation 1 by expressing the dependent variable and the independent variables in natural logarithmic forms, except for the closeness to State institutions variable. This model is shown in Equation 2 with $\mathrm{W}$ the error term, and $\mathrm{C}_{\mathrm{i}}(\mathrm{i}=1 \ldots . .5)$ the parameters.

$$
\ln Y=C_{0}+C_{1} \ln X_{1}+C_{2} \ln X_{2}+C_{3} \ln X_{3}+C_{4} \ln X_{4}+C_{5} \ln X_{5}+W
$$

Equation 2

Equation 2 was initially estimated by the ordinary least squares (OLS) estimation procedure. For the OLS parameters to be efficient and unbiased, the population equation error term must have a mean value of zero and constant variance (Hill et al; 2018). The OLS estimation of parameters, using cross-sectional data obtained from this study, involves diagnostic tests for the four major econometric problems. These four problems are (1) model mis-specification, (2) non-normality of the equation error term, (3) heteroscedasticity, and (4) multicollinearity. Heteroscedasticity was detected in the OLS estimation. This resulted in the use of the Generalized Least Squares (GLS) method to eliminate the problem based on the transformation of the dependent and independent variables by a factor related to the population variable. The description of the explanatory variables and their a priori effects are indicated in Table 1.

Table 1. Description of the explanatory variables used in the hedonic pricing model

\begin{tabular}{|c|c|c|c|}
\hline & Definition & Measurement & A priori effect \\
\hline$X_{1}$ & Distance from land to Tamale CBD & Meters & - \\
\hline$X_{2}$ & Distance from land to main road & Meters & - \\
\hline$X_{3}$ & Distance from land to the district capital & Meters & - \\
\hline$X_{4}$ & Number of people in the community & Urbanization & + \\
\hline$X_{5}$ & Closeness of land to nearest State institutions & 1 if yes and 0 if no & + \\
\hline
\end{tabular}

\subsection{Determining the Effects of Urbanization on Arable Land Use Changes}

GIS and remote sensing data were used to capture the changes in vegetation land cover and land uses. The secondary data were satellite images of the land in the Sagnarigu district; these were obtained using Microsoft Earth Explorer for the years, 2000, 2010 and 2020. Landsat imageries from 2000, 2010, and 2020 were acquired and analyzed to identify land-use changes over time. Multispectral images of Landsat 8 Operational Land Imager (OLI) were obtained for the year 2020, Landsat 7 Enhanced Thematic Mapper Plus (ETM+) images for the year 2010, Landsat 5 Thematic Mapper (TM) images for the year 2000 from https://earthexplorer.usgs.gov/. The Landsat images are earth observation images from the United States Geological Survey (USGS) Centre for Earth Observation and Science. Data collected were within the same season. The details of the methods used to assign the different land uses are available (Abubakari,

\section{0).5. Results and Discussion}

\subsection{Socioeconomic Characteristics of the Sampled Households}

The socioeconomic characteristics of the 300 sampled households are summarized in Table 2. Almost nine out of ten household heads were male. The majority of the household heads were in the middle-age group of between 36 to 50 years. Household heads, considered to be young, as defined by the Ghana Statistical Service (2013), are those aged between 15 to 35; these people constituted $13 \%$ of the sample. The average age was 47.2 years (see Table 3 ). The vast majority of the household heads were married (95.7\%); about two-thirds (67.7\%) of them had never been to school. The heads were mainly Muslims (95\%) and Dagombas (99.3\%). The average household size was 8.8, ranging from 1 to 25 (Table 3). Household incomes and expenditures are also reported in Table 3. The average monthly household farm income per person was 367.46 Ghana cedis translating to 64.41 US dollars in 2020 based on the average exchange rate of 5.705 Ghana cedis per one US dollar for 2020. 
Table 2. Characteristics of survey respondents using frequency analysis

\begin{tabular}{|c|c|}
\hline Item/group & Percent \\
\hline $\begin{array}{l}\text { Sex of household head } \\
>\quad \text { Female } \\
>\quad \text { Male }\end{array}$ & $\begin{array}{l}11.0 \\
89.0\end{array}$ \\
\hline $\begin{array}{l}\text { Age group } \\
>\quad 20-35 \\
>\quad 36-50 \\
>\quad 51-65 \\
>\quad \text { Over } 65 \\
\end{array}$ & $\begin{array}{c}13.0 \\
56.7 \\
26.6 \\
3.7\end{array}$ \\
\hline $\begin{aligned} & \text { Marital status } \\
&> \text { Currently Married } \\
&> \text { Single } \\
&> \text { Widowed }\end{aligned}$ & $\begin{array}{l}95.7 \\
2.3 \\
2.0\end{array}$ \\
\hline $\begin{array}{l}\text { Educational level } \\
>\quad \text { No schooling } \\
>\quad \text { Completed primary school } \\
>\quad \text { Completed secondary school } \\
>\quad \text { Completed Arabic school } \\
>\quad \text { Acquired post-secondary tertiary (university) qualifications }\end{array}$ & $\begin{array}{l}67.7 \\
10.3 \\
14.3 \\
2.3 \\
5.3\end{array}$ \\
\hline $\begin{array}{l}\text { Religious affiliation } \\
>\quad \text { Islam } \\
>\quad \text { Traditional African religions } \\
\quad \text { Christianity } \\
\end{array}$ & $\begin{array}{c}95.0 \\
4.0 \\
1.0\end{array}$ \\
\hline $\begin{array}{c}\text { Ethnicity (tribe) } \\
>\text { Dagomba } \\
>\text { Mossi }\end{array}$ & $\begin{array}{c}99.3 \\
0.7 \\
\end{array}$ \\
\hline $\begin{array}{cl}\text { Occupation outside crop farming } \\
>\text { Self employment } \\
>\quad \text { Livestock production } \\
>\quad \text { Crop production only } \\
>\quad \text { Trading } \\
>\quad \text { Government sector employee } \\
>\text { Private sector employee } \\
>\text { Retired persons } \\
\end{array}$ & $\begin{array}{c}44.3 \\
16.7 \\
14.3 \\
14.3 \\
5.3 \\
4.0 \\
1.0 \\
\end{array}$ \\
\hline $\begin{array}{l}\text { Household size } \\
\begin{array}{l}> \\
>\end{array} \quad 6 \text { to } 10 \\
>\quad 11 \text { to } 20 \\
>\quad 21 \text { and above }\end{array}$ & $\begin{array}{c}16.7 \\
61.0 \\
20.6 \\
1.7\end{array}$ \\
\hline
\end{tabular}

Source: Survey data, January to June 2020

Table 3. Average values of selected demographic characteristics, and incomes and expenditures incurred by respondents

\begin{tabular}{|l|c|}
\hline Item & Average \\
\hline Age in years & 47.2 \\
\hline Size of household & 8.8 \\
\hline Monthly household expenditure on food (Ghana cedis) & 220.91 \\
\hline Monthly household expenditure on water (Ghana cedis) & 50.04 \\
\hline Monthly household expenditure on electricity (Ghana cedis) & 57.17 \\
\hline Monthly household expenditure on cooking energy (charcoal and wood) (Ghana cedis) & 47.58 \\
\hline Monthly total household farm income (Ghana cedis) & $3,233.69$ \\
\hline Monthly household farm income per person (Ghana cedis) & 367.46 \\
\hline
\end{tabular}

Source: Survey data, January to June 2020

\subsection{Land Ownership and Land Use Types of the Sampled Households}

Table 4 indicates the nature of land ownership and the different types of land uses of the sampled households. The household heads were mainly semi-subsistence agricultural producers $(87.0 \%)$; they produced products for sale and also produced food to meet part of their household requirements. In terms of land ownership, about seven out of eight $(88.3 \%)$ of the household heads were customary land owners who enjoyed usufructuary rights to the land pieces that they used for farming but were not full owners, as ownership of the land was held in common by all members of the clan. All the tenant farms, with the exception of one, paid for the use of land through a share of the proceeds from 
production. That one particular tenant-farmer was responsible for taking care of the land and ancillary property owned by the landlord.

About four out of five households had between zero to five acres of land for farming. In terms of land-use experience, about nine of ten households $(91 \%)$ had less than 21 years of experience. The remaining nine percent had land-use experience of 21 years and over. Household heads declared their perceptions of the effects of continuous use of the same piece of land over time. Close to two-thirds of them indicated negative effects of declining soil fertility from the continuous use of the same piece of land. Only $13.7 \%$ of the household heads suggested little or no effect, largely due to their ability to acquire new pieces of land for farming when required.

Slightly over three-quarters (75.7\%) of the 300 responding household heads indicated losses of arable lands for farming to developers (refer to Table 5 for the sizes of land losses). In total, 999.5 acres of land were reported to have been lost by 227 households due to the expansion of built-up facilities in their communities. This particular result, when combined with the finding shown in Table 4 of the majority of households experiencing problems in the management of land, suggested pressure on households in finding land for farming. Given that the majority of the households did not fallow their land and continuously used the same pieces of land, increasing land insecurity could be inferred from this behaviour, similar to other findings reported in the literature, for example by Ayamga et al., 2015 and Acheampong et al., 2021.

Table 4. Summary information with regard to the nature of land ownership and use of land declared by the survey respondents based on frequency analysis

\begin{tabular}{|c|c|}
\hline Item/ group & Percent \\
\hline Type of farming & \\
\hline Subsistence & 5.0 \\
\hline$>$ Commercial & 8.0 \\
\hline$>$ Semi-subsistence & 87.0 \\
\hline Land ownership & \\
\hline$>$ Usufructuary ownership based on customary land rules & 88.3 \\
\hline$>$ Borrowed (tenant) & 5.7 \\
\hline$>$ Squatting & 6.0 \\
\hline Condition specified for holding or using land & \\
\hline No condition given the usufructuary ownership of land & 88.3 \\
\hline Share the produce generated from the farm & 11.3 \\
\hline Take care of the land & 0.4 \\
\hline Farm size in acres & \\
\hline$>\quad 0.5$ to 5.0 & 80.3 \\
\hline$>\quad 6.0$ to 10.0 & 16.0 \\
\hline$>\quad 11.0$ to 15.0 & 2.7 \\
\hline$>\quad 16.0$ to 20.0 & 0.7 \\
\hline$>\quad$ Over 20.0 & 0.3 \\
\hline Number of years of using the land parcel currently being farmed on & \\
\hline 1 to 5 & 19.3 \\
\hline$>6-10$ & 37.0 \\
\hline$>11-15$ & 16.7 \\
\hline$>16-20$ & 18.0 \\
\hline$>\quad$ More than 20 & 9.0 \\
\hline Problem arising from availability of land for farming & \\
\hline$>\quad$ No problem/land is available for farm expansion & 13.7 \\
\hline Difficult to expand the size of farm due to unavailability of land & 22.0 \\
\hline Soil is no longer fertile and yields of crops have been declining & 63.7 \\
\hline No money to buy capital inputs such as fertilizers to replenish the land & 0.7 \\
\hline
\end{tabular}

Source: Survey data, January to June 2020 
Table 5. Estimated loss of land in acres to developers due to the expansion of built-up areas into their communities declared by the responding household heads

\begin{tabular}{|c|c|c|c|}
\hline Loss of land in acres & Number of farmers & Total loss of land in acres & Percentage of respondents \\
\hline Never lost land & 73 & 0.0 & 24.3 \\
\hline 0.5 & 1 & 0.5 & 0.3 \\
\hline 1.0 & 16 & 16.0 & 5.3 \\
\hline 2.0 & 51 & 102.0 & 8.7 \\
\hline 3.0 & 26 & 78.0 & 15.0 \\
\hline 4.0 & 45 & 180.0 & 13.0 \\
\hline 5.0 & 39 & 195.0 & 7.7 \\
\hline 6.0 & 23 & 138.0 & 0.3 \\
\hline 7.0 & 1 & 7.0 & 3.7 \\
\hline 8.0 & 11 & 88.0 & 3.0 \\
\hline 15.0 & 9 & 90.0 & 0.3 \\
\hline 20.0 & 1 & 15.0 & 1.0 \\
\hline 30.0 & 3 & 60.0 & 0.3 \\
\hline Total & 1 & 30.0 & \\
\hline
\end{tabular}

Source: Survey data, January to June 2020

\subsection{Results from the Regression Analysis of Factors Influencing Arable Land Values}

The second objective of the study sought to ascertain the factors influencing arable land values, based on assessment by experts in land valuation, coupled with information from chiefs of the area, and the responding household heads. This second objective was tackled with the use of a hedonic pricing model which related the value of piece of land used by farmers to a number of independent variables. The results of the GLS regression model analysis of the land values are presented in Table 6. An important diagnostic test used for a cross-sectional model is its adequate specification. The specification test conducted was the Ramsey Reset Test (Ramsey, 1969). The computed $p$ value of this test was 0.210 , which was above the 0.05 (5\%), the maximum significance level used in this study. Therefore, it was concluded that the model was adequately specified. The normality of the equation error term is required to generalize the parameter estimates of the sample to the parameter values of the population. Given the relatively large sample size (122), normality was assumed based on the central limit theorem (refer to Montgomery and Runger, 2014).

The third important diagnostic test is heteroscedasticity which is known to be common with cross-sectional data. Two common tests of heteroscedasticity are the Glejser test (Glejser, 1969), and the Lagrange Multiplier (LM) test (Breusch and Pagan, 1979), were undertaken; the results confirmed the absence of heteroscedasticity with the computed p-values, 0.185 and 0.808 , for the Glejser test and LM test respectively, above the critical significance value of 0.05 . The fourth diagnostic test conducted was multicollinearity. Multicollinearity measures the degree of dependence among the independent variables. If the independent variables are strongly related, then the standard errors of the parameter estimates are unnecessarily amplified. A common test for multicollinearity is the variance inflation factor (VIF) which establishes the degree of amplification of the variance of the parameter estimate. Values of VIF greater than 10.0 could suggest a problem of multicollinearity (Hill et al., 2018). As shown in Table 6, all the VIFs of the independent variables were below the critical value of 10.0 indicating insignificant multicollinearity in the model.

The power of the model is important to consider in the model as it measures the degree of the variation in the dependent variable explained by the independent variables. In this model, a common measure of the power of the model, the $\mathrm{R}^{2}$, was 0.867 . This meant that $86.7 \%$ of the variation in the dependent variable was explained by the five independent variables. This result suggested a very high power of the model. As shown in Table 6, all the five independent variables statistically influenced the value of land. These are as follows: (1) distance to the Tamale CBD, (2) distance to the nearest main road, (3) distance to the capital city, (4) population, and (5) closeness to State institutions. Based on the standardized regression estimates noted in Table 6, the most important independent variable affecting the value of land was population.

As expected, for the three distance-related variables, their effect on the value of land was negative implying that the farther away the land was from the selected place, the lower its financial value. These results were similar to findings in the literature which showed that prices of land increased in urban areas due to their location closer to central points of business and political power. The negative effect on land values due to the increase in the distance of agricultural land to city centres has been reported (for example, refer to Guiling et al., 2009; Alam, 2018). The positive effect of population size, which was a proxy for the degree of urbanization, on the value of land, was in line with a priori expectation. This result identified was similar to the finding shown in some studies which indicated the positive effect of urbanization on arable land prices (Plantiga et al., 2002; Kuethe et al., 2011). However, some studies indicated 
opposite results (for example, Shi et al., 1997; Pietola et al., 2011). These other studies suggested that changes in land prices were related to the expected capital gains on the land rather than its location and distance from urban centres. The positive significant effect on the value of land due to its closeness to State institutions was also established in this study (refer to Table 6).

Table 6. Multiple regression analysis estimates of the parameters of the variables influencing the value of land in the Sagnarigu district based on the use of the GLS estimation procedure

The dependent variable is LLANDVALUE - the natural logarithm of the value of land

\begin{tabular}{|l|c|c|c|c|c|}
\hline \multicolumn{1}{|c|}{ Explanatory Variable } & $\begin{array}{c}\text { Parameter } \\
\text { Estimate }\end{array}$ & $\begin{array}{c}\text { Standardized } \\
\text { Parameter } \\
\text { Estimate }\end{array}$ & $\begin{array}{c}\text { Student } \\
\text { t-Test Value }\end{array}$ & $\begin{array}{c}\text { Significance } \\
\text { Probability }\end{array}$ & $\begin{array}{c}\text { VIF } \\
\text { INTERCEPT }\end{array}$ \\
\hline LDISTANCETOTAMALECBD & -22.405 & 0.000 & -17.853 & $0.000^{* * *}$ & 0.000 \\
\hline LDISTANCETOMAINROAD & -0.980 & -0.613 & -6.133 & $0.000^{* * *}$ & 8.733 \\
\hline LDISTANCETODISTRICTCAPITAL & -0.369 & -0.256 & -7.240 & $0.000^{* * *}$ & 1.095 \\
\hline LPOPULATION & -0.337 & -0.208 & -2.550 & $0.012^{* *}$ & 5.833 \\
\hline CLOSENESSTOSTATEINSTITUTIONS & 26.360 & 1.004 & 18.749 & $0.000^{* * *}$ & 2.508 \\
\hline
\end{tabular}

Notes: $* *$ denotes $1 \%$ significance level; $* *$ denotes $5 \%$ significance level

\subsection{Effect of Urbanization on Arable Land Use Changes}

The third objective of this study sought to analyze the effect of urbanization and population increase on arable land-use changes. The related research question was to what extent had urbanization affected land use patterns in the study area. A spatial analysis of satellite images was done to establish the land cover changes, in the study area, based on data in 2000, 2010 and 2020. Figure 1 provides information about the land use and land cover in the Sagnarigu district for the years 2000, 2010 and 2020, measured in square kilometres $\left(\mathrm{km}^{2}\right)$.

Sagnarigu district has a total land area of $200.4 \mathrm{~km}^{2}$. Using Figure 1, it is observed that in the year $2000,9.6 \mathrm{~km}^{2}$ of land were covered by vegetation, $177.8 \mathrm{~km}^{2}$ of land were classified as bare/arable land, while $13.0 \mathrm{~km}^{2}$ were classified as built-up areas. In 2010, the area covered by vegetation increased to $33.8 \mathrm{~km}^{2}$; possibly arising from increased agricultural production from rapidly-growing population. This resulted in bare/arable land area declining to $102.7 \mathrm{~km}^{2}$. In 2010, the built-up area increased sharply from $13.0 \mathrm{~km}^{2}$ in 2000 to $63.8 \mathrm{~km}^{2}$. In 2020, the area covered by vegetation declined considerably from $33.8 \mathrm{~km}^{2}$ in 2010 to $10.2 \mathrm{~km}^{2}$; bare/arable land area declined modestly from $102.7 \mathrm{~km}^{2}$ in 2010 to $92.7 \mathrm{~km}^{2}$ in 2020 . The built-up area again increased sharply from $63.8 \mathrm{~km}^{2}$ in 2010 to $97.5 \mathrm{~km}^{2}$ in 2020 .

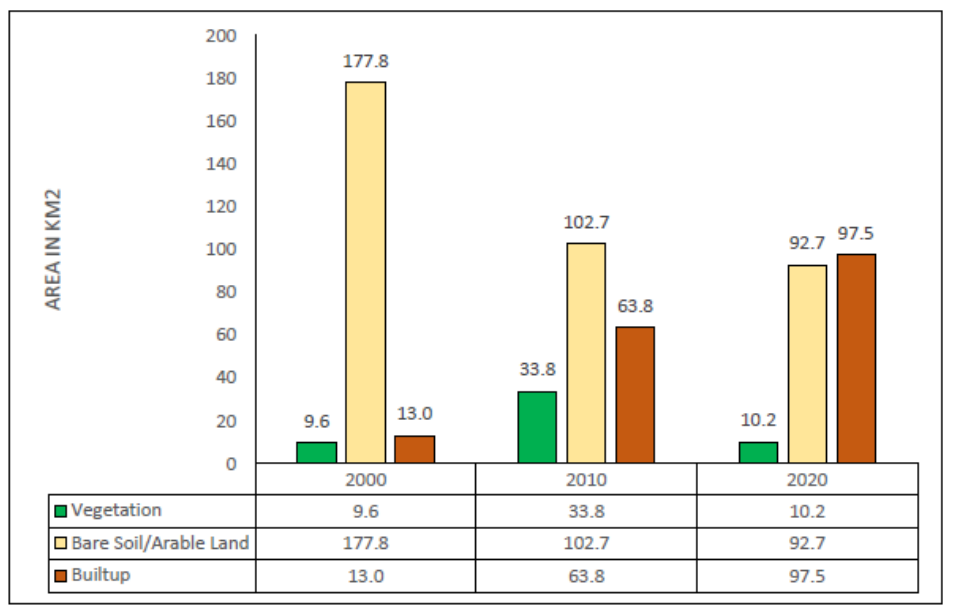

Figure 1. Land Use Land Cover for the Years 2000, 2010, and 2020 in $\mathrm{Km}^{2}$

Source; Field Data, 2020

As indicated in Figure 2, there were gains and losses for land areas related to vegetation. The land area under vegetation cover increased from 2000 to 2010 but then declined sharply from 2010 to 2020 . The land area covered by vegetation would indicate areas devoted to agricultural and forestry uses. The amount of bare/arable land decreased during both 
time intervals, that is from 2000 to 2010, and 2010 to 2020. For the built-up area, the size increased over both time intervals. Overall, the built-up area increased from $13.0 \mathrm{~km}^{2}$ in 2000 to $97.5 \mathrm{~km}^{2}$ in 2020, an astronomical increase of $650 \%$ from 2000 to 2020. By 2020, the built-up area had become the largest source of land use of all the three types, accounting for $48.7 \%$ of the total land available in the district, compared to its shares of $6.5 \%$ in 2000 , and $31.8 \%$ in 2010.

In particular, the land use pattern changes from 2010 to 2020 are noticeably. In 2010, vegetation was noticeably around the boundaries of the district and selected areas within the centre of the district. However, ten years later, in 2020, vegetation was noticeably absent in many areas around the boundaries of the district replaced by built-up areas. Virtually, all the green areas around the boundaries of the district noted in 2010 had disappeared in 2020, except in a few areas of the southern fringes of the district. The vegetative areas had been replaced with built-up structures.

Increase in urbanization, indicated by the size of built-up area reduced the size of arable lands, especially around the boundaries of the district. The expansion of built-up area arose from the demand of land by developers used for the construction of residential accommodation facilities, and government offices in newly-created districts and sub-districts. Further the expansion of businesses in tourism and other sectors of the economy led to an expansion of the built-up areas of the district amidst the fast growth of the population of the Greater Tamale Area. The finding of this study is similar to those established by other research workers (for example, refer to the studies conducted by Fazal, 2000; Kerschner and O’Neill; 2015: Pandey et al., 2015; Mbaya et al., 2019).

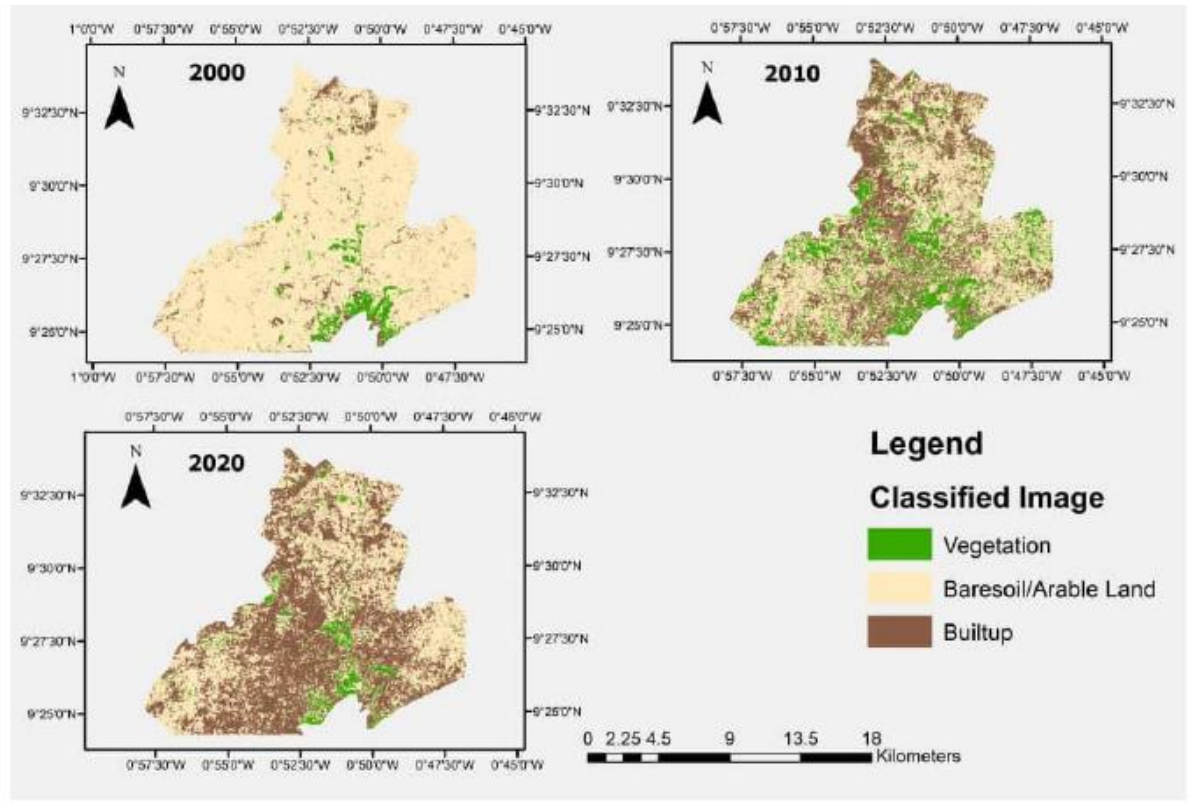

Figure 2. Overlaid Classified Images of Sagnarigu Municipality (2000, 2010, 2020)

Source; Field Data, 2020

\section{Conclusions and Recommendations}

\subsection{Conclusions}

This study assessed the nature of land tenancy status of 300 randomly-selected farmers in the Sagnarigu district of the Northern Region of Ghana. It also analysed the factors influencing the value of land, and ascertained the effects of increasing population and urbanization on arable land-use changes in the district. About seven out of eight responding heads were users of land within a system of joint communal ownership (usufructuary owners). The remaining respondents were tenants. The study established that even though usufructuary ownership of land was common in the Sagnarigu district, there was high level of land tenure insecurity arising from sales of communal land to developers for the construction of built-up facilities. About three-quarters of the respondents indicated loss of arable lands to developers. The results of the study tended to support the use of the cooperative household theory, based on the dominance of currently-married household heads, and with household members, including spouses, engaged in various work activities.

The major factors that significantly influenced the economic value of land was derived using hedonic pricing analysis. The three significant negative factors were (1) distance to the Tamale CBD, (2) distance to the nearest main road, and 
(3) distance to the district capital town. Increasing population and closeness to State institutions positively influenced the value of land. We also established that the built-up area in the district increased from $13.0 \mathrm{~km}^{2}$ in 2000 to $97.5 \mathrm{~km}^{2}$ in 2020, an increase of $650 \%$ from 2000 to 2020. By 2020, the built-up area had become the largest source of land use of all the three types, accounting for $48.7 \%$ of the total land available, compared to $6.5 \%$ in 2000, and 31.8\% in 2010.

\subsection{Policy Recommendations}

In this study, we show that economic growth, arising from the rapid conversion of environmental capital inputs into human-made assets, imposes negative societal impacts, exemplified by large losses of arable lands, indicated by the respondents. Given that many of the farmers in the study area do not have the technical skills to move into the non-farming sectors of the wider economy, and considering the rapidly growing population, the problem of large losses of arable lands needs to be ameliorated through State interventions to pre-empt occurrences of public insecurity driven by increased unemployment and underemployment of displaced farmers.

We make some recommendation as follows: There should be a land-use policy within the urban planning institutions to preserve green spaces in the urban and peri-urban areas in order to protect urban and peri-urban agriculture to provide agricultural employment. Rapid urbanization causes land price increases which lead to excessive land speculation in urban and peri-urban areas where the urban rich takes advantage of the weak land management systems to purchase lands, which mostly are arable lands. Some traditional land custodians also take advantage of the higher demand for land to supply land to urban developers; this results in an uncontrolled land market in the urban and urban fringes. To curb this phenomenon, it is important that the government fulfills its obligations to strengthen urban land-use planning systems so that there is increased stakeholder participation in land use planning to prevent the indiscriminate arable land sale. Finally, the government should encourage vertical-type building construction for commercial and residential purposes.

\section{Acknowledgments}

This article was developed from the Master of Philosophy in Agribusiness degree thesis produced by the senior author and submitted to the University of Ghana, Legon, Accra in December 2020.

\section{References}

Abubakari, M. M. (2020). Effects of Urbanization on Arable Land Use Changes in Sagnarigu Municipality in the Northern Region. Master of Philosophy in Agribusiness Thesis, University of Ghana, Legon, Accra, Ghana.

Acheampong, E. O., Sayer, J., MacGregor, C. J., \& Sloan, S. (2021). Factors influencing the adoption of agricultural practices in Ghana's forest-fringe communities. Land, 1-21. https://doi.org/10.3390/land10030266

Adams, M., \& Adams, M. (2001). Tenure Security, Livelihoods and Sustainable Land Use in Southern Africa. London: Department of Foreign and International Development.

Alam, M. J. (2018). Rapid urbanization and changing land values in mega cities: implications for housing development projects in Dhaka, Bangladesh. Bandung: Journal of the Global South, 5(1), 1-19. https://doi.org/10.1186/s40728-018-0046-0

Alemu, T. (1999). Land Tenure and Soil Conservation: Evidence from Ethiopia. PhD Thesis, Department of Economics, University of Gothenburg, Gothenburg, Germany.

Amoah, A., \& Korle, K. (2020). Forest depletion in Ghana: the empirical evidence and associated driver intensities. Forestry Economics Review, 2(1), 61-80. https://doi.org/10.1108/FER-12-2019-0020

Anaman, K. A. (1988). African Farm Management: Principles and Applications with Examples. Accra: Ghana Universities Press.

Anaman, K. A. (2001). Supply response of rice in Brunei Darussalam. Borneo Review, 12(2), 171-183.

Anaman, K. A. (2014). Research Methods in Economics and Other Social Sciences. Saarbrucken, Germany: Lambert Academic Publishing.

Anaman, K. A., \& Agyei-Sasu, F. (2014). The economic value of the environmental capital inputs used to produce gross domestic product in Ghana, 1993 to 2012. Research in World Economy, 5(2), 74-92. https://doi.org/10.5430/rwe.v5n2p74

Anaman, K. A., \& Bukari, G. A. (2019). Political economy analysis of voter participation and choices in national elections in Ghana's fourth republican era. Research in World Economy, 10(3), 174-198. https://doi.org/10.5430/rwe.v10n3p174

Anaman, K. A., \& Bukari, G. A. (2021). Voter turnouts in presidential elections in Ghana: A political economy analysis using district-level data. Applied Economics and Finance, 8(1), 13-31. https://doi.org/10.11114/aef.v8i1.5083 
Anaman, K. A., Lellyett, S. C., \& Avsar, G. S. (2000). Assessing the effect of aviation weather forecasts on fuel expenditures of an international airline. International Journal of Transport Economics, 27(2), 257-277.

Anaman, K. A., Quaye, R., \& Amankwah, E. (2017). Evaluation of public weather services by users in the formal services sector in Accra, Ghana. Modern Economy, 8, 921-945. https://doi.org/10.4236/me.2017.87065

Appiah, D. O., Bugri, J. T., Forkuo, E. K., \& Boateng, P. K. (2014). Determinants of peri-urbanization and land use change patterns in peri-urban Ghana. Journal of Sustainable Development, 7(6), 95-109. https://doi.org/10.5539/jsd.v7n6p95

Ayamga, M., Yeboah, R. W., \& Dzanku, F. M. (2015). Determinants of farmland tenure security in Ghana. Ghana Journal of Science, Technology and Development, 2(1), 1-21. https://doi.org/10.47881/43.967x

Azadi, H., Ho, P., \& Hasfiati, L. (2010). Agricultural land conversion drivers: A comparison between less developed, developing and developed countries. Land Degradation \& Development, 22(6), 596-604. https://doi.org/10.1002/ldr.1037

Baimbill-Johnson, N., Anaman, K. A., \& Amegashie, D. (2021). Evaluation of the resource efficiency of guinea fowl production in the Savelugu-Nanton district of the Northern Region of Ghana. Journal of Development and Agricultural Economics, 13(2), 132-145. https://doi.org/10.5897/JDAE2020.1223

Bank of Ghana (2022). Summary of Economic and Financial Data January 2022. Accra: Bank of Ghana.

Bartik, T. J. (1987). The estimation of demand parameters in hedonic price models. Journal of Political Economy, 95(1), 81-88. https://doi.org/10.1086/261442

Bayo, A. O. (2006). City planning, city growth and food security: The inevitable trinity in the Nigerian food equation. Agricultural Journal, 1(3), 113-118.

Blomley, T., Roe, D., Nelson, F., \& Flintan, F. (2013). Land Grabbing: Is Conservation Part of the Problem or the Solution? London: International Institute for Environment and Development.

Bloomberg News (2022). Ghana Debt Dips Deeper into Distress as Investors Quit. Retrieved from https://www.bloomberg.com/news/articles/2022-01-13/ghana-debt-moves-deeper-into-distress-as-investors-lose-pa tience, accessed 24 January 2022.

Breusch, T. S., \& Pagan, A. R. (1979). A simple test for heteroskedasticity and random coefficient variation. Econometrica, 47(5), 1287-1294. https://doi.org/10.2307/1911963

British Broadcasting Corporation (BBC). (2021). The Illegal Gold Miners Killing Rivers and Livelihoods in Ghana Documentary. London: BBC, 11 August.

Brown, J. N., \& Rosen, H. S. (1982). On the estimation of structural hedonic price models. Econometrica, 50(3), 765-768. https://doi.org/10.2307/1912614

Chiappori, P. A., Haddad, L., Hoddinott, J., \& Kanbur, R. (1993). Unitary Versus Collective Models of the Household: Time to Shift the Burden of Proof? Washington, D.C.: World Bank.

Cobbinah, P. B., Erdiaw-Kwasie, M. O., \& Amoateng, P. (2015). Rethinking sustainable development within the framework of poverty and urbanization in developing countries. Environmental Development, 13, 18-32. https://doi.org/10.1016/j.envdev.2014.11.001

Damba, O. T., Abarike, M. A., Nabilse, C. K., \& Akudugu, M. A. (2019). Urban poverty analysis in Tamale, Ghana. UDS International Journal of Development, 6(2), 79-96.

Daniel, S. (2011). Land grabbing and potential implications for world food security. Sustainable Agricultural Development, Dordrecht, Germany: Springer, 25-42. https://doi.org/10.1007/978-94-007-0519-7

De Vaus, D. (2014). Surveys in Social Research (6th ed.). London: Routledge/Taylor and Francis. https://doi.org/10.4324/9780203519196

Engstrom, G., \& Gren, A. (2017). Capturing the value of green space in urban parks in a sustainable urban planning and design context pros and cons of hedonic pricing. Ecology and Society, 22(2), 21. https://doi.org/10.5751/ES-09365-220221

Fazal, S. (2000). Urban expansion and loss of agricultural land-a GIS based study of Saharanpur City, India. Environment and Urbanization, 12(2), 133-149. https://doi.org/10.1177/095624780001200211

Food and Agriculture Organization (FAO). (2011). Price Volatility in Food and Agricultural Markets: Policy Responses. Rome: FAO.

Ghana Environmental Protection Agency (GEPA). (2019). Ghana's Fourth National Greenhouse Gas Inventory Report: 
National Greenhouse Gas Inventory to the United Nations Framework Convention on Climate Change. Accra: GEPA.

Ghana Statistical Service (GSS) (2021). 2021 Population and Housing Census General Report Volume 3A Population of Regions and Districts. Accra: GSS.

Ghana Statistical Service (GSS). (2013). 2010 National Population and Housing Census: National Analytical Report. Accra: GSS.

Ghana Statistical Service (GSS). (2014a). 2010 National Population and Housing Census: District Analytical Report Tamale Metropolis. Accra: GSS.

Ghana Statistical Service (GSS). (2014b). 2010 National Population and Housing Census: District Analytical Report Sagnarigu. Accra: GSS.

Ghana Statistical Service (GSS). (2018). Ghana Living Standards Survey Round 7 (GLSS) 7 Poverty Trends in Ghana 2005-2017. Accra: GSS.

Ghebru, H., \& Lambrecht, I. (2017). Drivers of perceived land tenure (in)security: empirical evidence from Ghana. Land Use Policy, 66, 293-303. https://doi.org/10.1016/j.landusepol.2017.04.042

Glejser, H. (1969). A new test for heteroscedasticity. Journal of the American Statistical Association, 64, 316-323. https://doi.org/10.1080/01621459.1969.10500976

Godfray, H. C. J., Beddington, J. R., Crute, I. R., Haddad, L., Lawrence, D., Muir, J. F., ... Toulmin, C. (2010). Food security: the challenge of feeding 9 billion people. Science, 327(5967), 812-818. https://doi.org/10.1126/science.1185383

Guiling, P., Brorsen, B. W., \& Doye, D. (2009). Effect of urban proximity on agricultural land values. Land Economics, 85(2), 252-264. https://doi.org/10.3368/le.85.2.252

Hicks, J. R. (1939). The foundations of welfare economics. The Economics Journal, 49(196), 696-712. https://doi.org/10.2307/2225023

Hill, R. C., Griffiths, W. E., \& Lim, G. C. (2018). Principles of Econometrics. London: Wiley.

Idoma, K., \& Ismail, M. (2014). The effects of land tenure practices on agricultural output in Agatu Local Government Area of Benue State, Nigeria. Journal of Development and Agricultural Economics, 6(5), 212-219. https://doi.org/10.5897/JDAE12.158

Iheke, O. R., \& Nto, P. O. (2010). Effect of population pressure/urbanization on the adoption of sustainable agricultural practices by farmers: a case study of South Eastern Nigeria. Journal of Food and Fiber Production 3(1), 543-549.

Johnston, M., Licker, R., Foley, J., Holloway, T., Mueller, N. D., Barford, C., \& Kucharik, C. (2011). Closing the gap: global potential for increasing biofuel production through agricultural intensification. Environmental Research Letters, 6, 034028. https://doi.org/10.1088/1748-9326/6/3/034028

Kerschner, C., \& O’Neill, D. W. (2015). Economic growth and sustainability. In Kopnina, H.; Shoreman, E. (eds.). Sustainability: Key Issues, Chapter 11, London: Routledge, 243-276. https://doi.org/10.4324/9780203109496-12

Kuethe, T. H., Ifft, J., \& Morehart, M. J. (2011). The influence of urban areas on farmland values. Choices, 26(2), 1-7.

Kusimi, B. A., Kusimi, J. M., \& Yiran, G. B. (2013). Socio-economic and environmental impacts of mining within the catchment of mining companies at Tarkwa. Ghana Social Science Journal, 10, 25-52.

Kuusaana, E. D., \& Eledi, J. A. (2015). As the city grows, where do the farmers go? understanding peri-urbanization and food systems in Ghana - evidence from the Tamale Metropolis. Urban Forum, 26(4), 443-465. https://doi.org/10.1007/s12132-015-9260-x

Lancaster, K. (1971). Consumer Demand A New Approach. New York: Columbia University Press.

Lasisi, M., Popoola, A., Adediji, A., Adedeji, O., \& Babalola, K. (2017). City expansion and agricultural land loss within the peri-urban area of Osun State, Nigeria. Ghana Journal of Geography, 9(3), 132-163.

Malik, R., \& Ali, M. (2015). The impact of urbanization on agriculture sector: a case study of Peshawar, Pakistan. Journal of Resource Development and Management, 8, 79-85.

Marshall, A. (1890). Principles of Economics. London: Macmillan Press.

Mbaya, L. A, Abu, G. O., Makadi, Y. C., \& Umar, D. M. (2019). Effect of urbanizaton on land use cover in Gombe Metropolis. British Journal of Earth Sciences Researc, 7(2), 53-61.

McMillan, M., Rodrik, D., \& Sepulveda, C. (eds.). (2017). Structural Change, Fundamentals and Growth. A Framework 
and Case Studies. Washington, D.C.: International Food Policy Research Institute. https://doi.org/10.3386/w23378

Montgomery, D. C., \& Runger, G. C. (2014). Applied Statistics and Probability for Engineers (6th ed.). London: Wiley Press.

Moreno, E. L. (2017). Concepts, definitions and data sources for the study of urbanization. The 2030 Agenda for Sustainable Development Produced by Experts Group on Cities, Human Mobility and International Migration. New York: United Nations.

Murphy, S. (2013). Land Grabs and Fragile Food Systems. Washington, D.C.: Institute for Agriculture and Trade Policy.

Naab, F. Z., Dinye, R. D., \& Kasanga, R. K. (2013). Urbanization and its impact on agricultural lands in growing cities in developing countries: a case study of Tamale in Ghana. Modern Social Science Journal, 2(2), 256-287.

Nguyen, T. T., Hegedüs, G., \& Nguyen, T. L. (2019). Effect of land acquisition and compensation on the livelihoods of people in Quang Ninh District, Quang Binh Province: labor and income. Land, 8(6), 91. https://doi.org/10.3390/land8060091

Norton, W. (1979). The relevance of von Thunen theory to historical and evolutionary analysis of agricultural land use. Journal of Agricultural Economics, 30, 39-47. https://doi.org/10.1111/j.1477-9552.1979.tb01476.x

Pandey, B., \& Seto, K. C. (2015). Urbanization and agricultural land loss in India: Comparing satellite estimates with census data. Journal of Environmental Management, 148, 53-66. https://doi.org/10.1016/j.jenvman.2014.05.014

Pauchard, A., Aguayo, M., Peña, E., \& Urrutia, R. (2006). Multiple effects of urbanization on the biodiversity of developing countries: the case of a fast-growing metropolitan area (Concepción, Chile). Biological Conservation, 127(3), 272-281. https://doi.org/10.1016/j.biocon.2005.05.015

Pietola, K., Myyra, S., \& Pouta, E. (2011). The effects of changes in capital gains taxes on land sales: empirical evidence from Finland. Land Economics, 87(4), 582-594. https://doi.org/10.3368/le.87.4.582

Place, F. (2009). Land tenure and agricultural productivity in Africa: a comparative analysis of the economics literature and recent policy strategies and reforms. World Development, 37(8), 1326-1336. https://doi.org/10.1016/j.worlddev.2008.08.020

Plantinga, A. J., Lubowski, R. N., \& Stavins, R. N. (2002). The effects of potential land development on agricultural land prices. Journal of Urban Economics, 52(3), 561-581. https://doi.org/10.1016/S0094-1190(02)00503-X

Ramsey, J. S. (1969). Tests for specification errors in classical linear least squares regression. Journal of the Royal Statistical Society, Series B, 350-371. https://doi.org/10.1111/j.2517-6161.1969.tb00796.x

Rondhi., M., Pratiwi., P. A., Handini, V. T., Sunartomo, A. F., \& Budiman, S. A. (2018). Agricultural land conversion, land economic value, and sustainable agriculture: a case study in East Java, Indonesia. Land, 7(4), 148. https://doi.org/10.3390/land7040148

Salifu, G. A-N., \& Anaman, K.A. (2019). A political economy of income diversification activities of rural households in the Northern Region of Ghana. Applied Economics and Finance, 6(5), 10-34.

Shi, Y. J., Phipps, T. T., \& Colyer, D. (1997). Agricultural land values under urbanizing influences. Land Economics, 73(1), 90-100. https://doi.org/10.2307/3147079

Simbizi, D. M. C., Zevenbergen, J. A., \& Bennett, R. M. (2013). What is land tenure security for rural small holders in Sub-Saharan African context: revisiting the concept. Proceedings of Annual World Bank Conference on Land and Poverty, 8-11 April 2013. Retrieved from http://intranet.itc.nl/papers/2013/conf/simbizi_wha.pdf

Sossou, S., \& Mbaye, A. A. (2018). Impact of land security on household's agricultural productivity in Benin. Asian Journal of Agricultural Extension, Economics \& Sociology, 28(3), 1-13. https://doi.org/10.9734/ajaees/2018/45205

Tenaw, S., Islam, K. M. Z., \& Parviainen, T. (2009). Effects of Land tenure and Property Rights on Agricultural Productivity in Ethiopia, Namibia and Bangladesh. Rome: Food and Agriculture Organization.

United Nations Habitat (2017). World Cities Report 2016: Urbanization and Development - Emerging Futures. New York: United Nations.

United Nations (2019). World Urbanization Prospects: The 2018 Revision. New York: United Nations Department of Economic and Social Affairs Population Division.

World Bank (2021). Country Data on Ghana. Retrieved from https://data.worldbank.org/indicator/SI.POV.GINI?locations=GH, retrieved 26 December 2021. 
World Health Organization (WHO) (2018). Road Traffic Accidents in Ghana World Life Expectancy. Retrieved from, www.worldlifeexpectancy.com, accessed 30 December 2021.

Yale University. (2021). 2020 Environmental Performance Index: Unsafe Sanitation. Retrieved from http://www.epi.yale.edu/epi-results/2020/component/usd, accessed on 14 November 2021

Yeboah, E., \& Shaw, D. P. (2013). Customary land tenure practices in Ghana: examining the relationship with land-use planning delivery. International Development Planning Review, 35(1), 21-39. https://doi.org/10.3828/idpr.2013.3

\section{Copyrights}

Copyright for this article is retained by the author(s), with first publication rights granted to the journal.

This is an open-access article distributed under the terms and conditions of the Creative Commons Attribution license which permits unrestricted use, distribution, and reproduction in any medium, provided the original work is properly cited. 